This is the version of the article accepted for publication in Human Rights Quarterly published by John Hopkins University Press: https://www.press.jhu.edu/journals/human rights quarterly/index.html

Accepted version downloaded from SOAS Research Online: http://eprints.soas.ac.uk/23313/

\title{
Document and analyse: The legacy of Klemperer, Fraenkel and Neumann for contemporary human rights engagement
}

\section{Luz Oette, School of Law, SOAS University of London}

Human rights discourse has been criticised for being legalistic, decontextualised and failing to focus on factors explaining violations. Victor Klemperer's diaries chronicled the life and suffering of a German Jew in Nazi Germany and the manipulation of language by a totalitarian regime. Ernst Fraenkel's Dual State and Franz Neumann's Behemoth set out theories offering profound insights into the legal and political nature of the Nazi system. Revisiting their work from a human rights perspective is richly rewarding, providing examples of engaged scholarship that combined documentation and critical analysis. Their writings hold important lessons for contemporary human rights engagement and its critics.

\section{Introduction}

The human rights movement and language of human rights has been the subject of sustained criticism. Besides its supposed Western liberal bias, critics have focused particularly on human rights as a mode of political engagement. Human rights discourse is seen as legalistic and decontextualised. Richard Wilson argued in 1997 that human rights reports "can depoliticise human rights violations by drawing attention away from structural processes of class or ethnic power, and reduce violations to a set of technical problems concerning the functioning of the legal system." While more recent human rights reports frequently address "root causes", they still suffer, according to Susan Marks, from false contingency where "human rights violations are made to seem random, accidental or arbitrary". ${ }^{2}$ Instead, she suggests an explanatory discourse focusing on "planned misery", which examines the "logic 
This is the version of the article accepted for publication in Human Rights Quarterly published by John Hopkins University Press: https://www.press.jhu.edu/journals/human rights quarterly/index.html

Accepted version downloaded from SOAS Research Online: http://eprints.soas.ac.uk/23313/

of particular socio-economic arrangements". ${ }^{3}$ David Kennedy maintains that the state centric and institutional focus of human rights ignores the economy and underlying structure, and undermines emancipatory discourse and possibility. ${ }^{4} \mathrm{He}$ depicts the human rights movement as part of the problem, which results in a bureaucracy that downgrades the legal profession, encourages false solidarity and grapples with the perils of representation. ${ }^{5}$ Human rights promotion can even, inadvertently, strengthen repressive states, and condemnation may serve as legitimation. ${ }^{6}$

Modes of resistance to Nazi Germany, and their significance and relevance for today's human rights practices, barely figure in these debates. This resistance included concerted efforts by victims and political activists to document and expose multiple abuses (that would today be recognised as serious violations of human rights and international humanitarian law where committed in the course of World War II). ${ }^{7}$ It was not, and could not have been, done with reference to (yet to be) internationally recognised human rights. ${ }^{8}$ This form of resistance was, in contrast to human rights engagement today, not primarily aimed at bringing about compliance through pressure in various fora, ${ }^{9}$ other than in individual cases, but regime change, that is defeat of the Nazis. What makes it of particular interest is that the factual documentation and reporting of Nazi violations was in several instances grounded in an analysis of the causes, system and methods of abuse of power, the role and relations of various actors, including beneficiaries, and of political and socio-economic structures and conditions. Therefore, although it predated the contemporary human rights system - or perhaps precisely because it did - this history is an important example of responses to repressive regimes and the lessons such practice may hold for human rights engagement today. Revisiting intellectual resistance to Nazi Germany that combined documentation and analysis, typically under conditions of great risk or forced exile, also offers a reminder that 
This is the version of the article accepted for publication in Human Rights Quarterly published by John Hopkins University Press: https://www.press.jhu.edu/journals/human rights quarterly/index.html

Accepted version downloaded from SOAS Research Online: http://eprints.soas.ac.uk/23313/

today's human rights system is built on extraordinary courage in the face of extreme abuse of power and unimaginable suffering. It provides an inspiring example of how those faced with a policy and practice designed to deliberately render its victims rightless ${ }^{10}$ to the point of annihilation used their faculties to expose not only the facts of abuse but also its underlying material conditions, enabling factors, and effects on individuals and society.

This article focuses on the key works of Victor Klemperer, Ernst Fraenkel and Franz Neumann, as examples of Nazi opponents who combined documentation and analysis. Klemperer did so in a clandestine, personal context, Fraenkel and Neumann overtly as part of the political struggle against Nazi Germany. Klemperer, Fraenkel and Neumann were three remarkable men with much in common. They were German Jews who had grown up and been educated in Germany prior to $1933 .{ }^{11}$ All three were opposed to the Nazis, and aware of the danger the new regime posed. They shared this background with millions of their compatriots. What makes their legacy special is that consciously, from the very beginning, they set out to use their intellectual powers to document and analyse the reality of Nazi rule. Their respective work, in different ways, contributed to the struggle against a seemingly unstoppable power. Significantly, it provided conceptual tools to shed light on the underlying ideas, structure and actual workings of the regime. This enabled them, who had involuntarily become outsiders in their own societies or exiles, to understand how an "Unrechtsstaat" is constructed and maintained, and how it uses language, law and power to manipulate, control, repress and, in many cases, destroy its subjects. Their work is testimony to the strength of analysis of individuals who had a keen sense of justice and the rule of law, which they had developed both as part of their intellectual formation and in response to being personally confronted with acute injustices. 
This is the version of the article accepted for publication in Human Rights Quarterly published by John Hopkins University Press: https://www.press.jhu.edu/journals/human rights quarterly/index.html

Accepted version downloaded from SOAS Research Online: http://eprints.soas.ac.uk/23313/

The approach of the three differed considerably, particularly between Klemperer and the two others, Fraenkel and Neumann. Klemperer wrote a diary, with the ostensible goal to "bear witness". ${ }^{12}$ This was both a psychological survival strategy, and a conscious effort to document in, at times excruciating, detail the nature and impact of the Nazi regime on those living under it, particularly its victims. The diary represented an act of inner resistance, aided by those close to Klemperer, and a means to chronicle developments as they were, rather than as a tool to expose violations at the time. Klemperer is by no means unique in using the means of a diary to record daily realities, either at the time or thereafter, and his work forms part of a larger body of literature of survivors and victims, of both Nazi Germany and other regimes. ${ }^{13}$ His contribution will therefore also be discussed with reference to diaries as a genre and tool for the documentation of what a regime does to people under its control.

Fraenkel and Neumann were both trained lawyers who later combined legal studies with political science enquiries, in the case of Neumann also as a member of the Frankfurt School. ${ }^{14}$ Fraenkel remained in Germany until 1938, secretly collecting a vast array of materials that enabled him to analyse the nature of the state and law in Nazi Germany from close up. On the basis of this research, he wrote "The Dual State" which was published in exile. ${ }^{15}$ This classic work highlighted the janus faced nature of Nazi Germany, arguing that the legal system maintained a formal, rule of law façade in respect of certain aspects of public life, particularly the economy, while simultaneously giving carte blanche to authorities and others to take prerogative measures that served the regime's interest. Neumann, who had escaped Germany shortly after the Nazis had come to power, is the author of another classic, "Behemoth", published in $1942 .{ }^{16}$ In an ambitious, far-reaching book, he situated Nazi Germany in broader political and economic developments, with particular reference to the Weimar Republic, identified the centres of power within the Nazi machinery, and uncovered 
This is the version of the article accepted for publication in Human Rights Quarterly published by John Hopkins University Press: https://www.press.jhu.edu/journals/human rights quarterly/index.html

Accepted version downloaded from SOAS Research Online: http://eprints.soas.ac.uk/23313/

the dynamics underpinning the dictatorial regime. The interests of monopoly capitalism and competing power elites (party, bureaucracy, army and industry) were central to his analysis that Nazi Germany had become an "Unstaat", which destroyed any legal protection and ultimately relied on naked terror.

Fraenkel's and Neumann's books were published during the war, and were highly influential at the time, as they documented, and helped to understand the complex realties of how the regime functioned. ${ }^{17}$ Their work has attracted considerable scholarly attention. ${ }^{18}$ The analysis has focused on their role as lawyers in the resistance to the Nazis, ${ }^{19}$ their contribution to the allied fight against Germany and plans for reconstruction, ${ }^{20}$ as well as their respective understanding of the rule of law, ${ }^{21}$ and the role of natural law. ${ }^{22}$ Fraenkel's notion of the dual state has been employed as a framework of analysis to examine legal developments in South Africa and Chile. ${ }^{23}$ Neumann's insights into how vague standards are used by powerful actors have been applied to critique the international legal system governing economic globalisation. ${ }^{24}$ Klemperer's diaries have become a major source for historians. Together with his seminal Lingua Tertii Imperii (LTI), ${ }^{25}$ they are seen as one of the most authoritative accounts of what life was like for a Jew in Nazi Germany, ${ }^{26}$ and analysis of the use of its language to enshrine and maintain power. ${ }^{27}$ Building on, and adding to this literature, this article revisits the work of Klemperer, Fraenkel and Neumann from a human rights perspective with a view to highlighting its significance and drawing lessons for engaged scholarship and practices. This is not merely of historical interest. It forms part of a broader challenge for those advocating human rights to fight injustice at a time when the role of human rights in this struggle is increasingly called into question. ${ }^{28}$

\section{Victor Klemperer}

\section{A. The diaries}


This is the version of the article accepted for publication in Human Rights Quarterly published by John Hopkins University Press: https://www.press.jhu.edu/journals/human rights quarterly/index.html

Accepted version downloaded from SOAS Research Online: http://eprints.soas.ac.uk/23313/

During his lifetime (1881-1960), Klemperer was known for his work on French literature he had been a Professor of Roman Language Studies at various points - and, following World War II, for his LTI, in which, drawing on his diaries, he dissected the language of the Third Reich. ${ }^{29}$ The posthumous publication of Klemperer's diaries in Germany in 1995 caused a storm. The diaries, covering the period from 1933-1945, were instantly hailed as the single most important work depicting daily life in Nazi Germany as experienced by a German Jew. ${ }^{30}$ Since then, the diaries have become a major source for historians, and form part of educational material in teaching about the Holocaust. ${ }^{31}$

Klemperer's diaries are an extraordinary text. The abridged version alone is 1524 pages long, beginning on 14 January 1933 and ending on 10 June $1945 .^{32}$ In the diaries, Klemperer describes events and shares his observations, on both personal matters (his wife, friends, acquaintances and pet) and political developments, and reflects on his and others' struggles, states of mind and emotions. All of this is interspersed with a sophisticated analysis of the way the Nazi system operated and impacted life in Germany. Klemperer's diaries are compelling because they represent the outcome of a conscious decision, "to bear witness". Klemperer was under no illusion about Nazi Germany from the very beginning. He had an astute appreciation of people's strengths and weaknesses, including his own, and the intellectual capacity and language skills to situate and analyse what he experienced in the broader context of European history and world politics. The language used reflected his position as someone who lived through the period as a forced outsider in what he considered his country, combining sober analysis with sarcasm and contempt for those whose conduct fell short of his standards. The diaries therefore provide both a highly personal but also objective account of how German Jews and other opponents or victims experienced Nazi Germany, particularly in Klemperer's circles, and were affected by its policies. ${ }^{33}$ This 
This is the version of the article accepted for publication in Human Rights Quarterly published by John Hopkins University Press: https://www.press.jhu.edu/journals/human rights quarterly/index.html

Accepted version downloaded from SOAS Research Online: http://eprints.soas.ac.uk/23313/

account chronicles and reflects on the conduct of perpetrators, victims and bystanders, and the population at large, painting a complex picture of reality in Nazi Germany.

Klemperer described a series of abuses he was subjected to as part of the Nazi's anti-semitic policy and practices. This included dismissal from work, expropriation, restrictions on his freedom of movement, privacy and family life, beatings, humiliation, lack of a fair trial and arbitrary detention, forced labour, and policy induced hunger and destitution that adversely impacted his health and standard of living. He also reported on detention, torture, other illtreatment, forced labour, and killings, including suicides born out of despair, that others he knew or heard about had suffered; in several instances, he witnessed these acts or their aftermath personally.

Klemperer's response, and that of many other German Jews in a similar situation who were unable or unwilling to escape in time, was characterised by a turmoil of emotions. The "systematic arbitrariness" of measures resulted in an increased sense of vulnerability and loss of dignity, ${ }^{34}$ reinforced by social isolation and loneliness. Fear, uncertainty and doubt were aggravated by an acute sense of his weakness, worries and, at times, indifference towards others. Klemperer did not give into suffering by committing suicide, also because of his determination to bear witness. It offered him an alternative space that he increasingly lacked in reality and enabled him to fight back by intellectually defying the Nazis through his analysis. This included writing and hiding the diaries, which was an incredibly risky undertaking, as he was well aware. ${ }^{35}$ When questioned by an acquaintance, Herr Stühler, why he bothered writing the diaries, Klemperer recounts the following dialogue:

[K:] I will bear witness. 
This is the version of the article accepted for publication in Human Rights Quarterly published by John Hopkins University Press: https://www.press.jhu.edu/journals/human rights quarterly/index.html

Accepted version downloaded from SOAS Research Online: http://eprints.soas.ac.uk/23313/

[S:] The things you write down, everybody knows, and the big things, Kiev, Minsk, etc. you know nothing about.

[K:] It's not the big things which are important to me but the every day life of tyranny, which gets forgotten. A thousand mosquito bites are worse than a blow to the head. ${ }^{36}$

One week later Stühler tells Klemperer:

I once read that fear of something is worse than the event itself. How I dreaded the house search. And when the Gestapo [(Geheime Staatspolizei-Nazi secret police] came, I was quite cold and defiant. And how our food tasted afterwards! All the good things, which we had hidden and they had not found. ${ }^{37}$

Klemperer replies:

You see, I'm going to note that down. ${ }^{38}$

As early as April 1933, Klemperer emphasised the sense of being exposed to arbitrariness and deprived of rights, knowing that the early legislative measures may be a prelude to murder. He clearly identified the self-destructive nature of the regime and its handling of the "Jewish question":

The fate of the Hitler movement will undoubtedly be decided by the Jewish business. I do not understand why they have made this point of their programme so central. It will sink them. But we will probably go down with them. ${ }^{39}$

From 1933 to 1939 Klemperer showed how the various discriminatory measures taken against Jews resulted in increasing impoverishment, isolation and resignation. It is a chilling chronic of how a state systematically strips members of a particular group of their rights, protection and self-respect. This was done by removing status, depriving Jews of their place 
This is the version of the article accepted for publication in Human Rights Quarterly published by John Hopkins University Press: https://www.press.jhu.edu/journals/human rights quarterly/index.html

Accepted version downloaded from SOAS Research Online: http://eprints.soas.ac.uk/23313/

in public life, robbing them of their possessions, and using a plethora of repressive measures and administrative means to exercise arbitrary control. Equally, it showed how a regime uses propaganda and a mixture of terror and promises to create an atmosphere of fear and conformity. In an observation that highlights the importance of diplomatic protest, Klemperer foreshadowed, in September 1936, the dangers of appeasement:

One always thinks that surely somewhere in Germany voices of shame and fear must be raised, protests must come from abroad, where everywhere (even in Italy, our ally!) there are Jews in the highest positions - nothing! Admiration for the Third Reich, for its culture, trembling fear of its army and its threats. ${ }^{40}$

This observation tied in with Klemperer's broader analysis of the importance of framing:

There is no German or West European Jewish question. Whoever recognises one, only adopts or confirms the false thesis of the NSDAP [National Socialist German Workers' Party] and serves its cause. ${ }^{41}$

The life of Jews in Germany took a dramatic turn for the worse during the war. Klemperer and others were visibly separated from the rest of society by having to live in "Jew houses". In September 1941, they were forced to wear the "Jewish star", a measure that was experienced as particularly pernicious and humiliating. ${ }^{42}$ Klemperer himself was increasingly subject to abuses. This took the form of arbitrary and violent searches by the Gestapo, and an eight day detention in June 1941 for failure to black out. ${ }^{43}$ From April 1943 to June 1944, he was compelled to undertake forced labour, which allowed him to portray in great detail the daily realities and political dynamics of his place of work's micro-society. Klemperer repeatedly described his sense of despondency and constant fear of death at the time: 
This is the version of the article accepted for publication in Human Rights Quarterly published by John Hopkins University Press: https://www.press.jhu.edu/journals/human rights quarterly/index.html

Accepted version downloaded from SOAS Research Online: http://eprints.soas.ac.uk/23313/

One no longer reckons on prison or a beating, but straightaway with death for everything and anything. ${ }^{44}$

Friends and acquaintances were driven to suicide, killed by the Gestapo, or deported, and there were increasing rumours and reports from trusted sources about concentration camps, including Auschwitz in 1942:

In the last few days I heard Auschwitz (or something like it) near Königshütte in Upper Silesia, mentioned as the most dreadful concentration camp. Work in a mine, death within a few days. $^{45}$

His end of year entry in 1942 captured the terror engulfing him:

Of the ten Nazi years thus far, this year of 1942 was the worst. We have suffered new humiliation, persecution, ill-treatment, slander. Murder splashed all around us, and every day we felt ourselves in mortal danger. And yet I can only say: Thus far the worst year, for there is every prospect that the terror will grow more intense, and there is no telling how long the war and this government will last. ${ }^{46}$

Throughout this period, Klemperer still found time to reflect on human survival in extraordinary times:

Today over breakfast we talked about the extraordinary capacity of human beings to bear and become accustomed to things. The fantastic hideousness of our existence: fear of every ring of the doors, of ill-treatment, insults, fear for one's life, of hunger (real hunger), ever new bans, ever more cruel enslavement, deadly danger coming closer every day, every day new victims all around us, absolute helplessness - and yet still hours of 
This is the version of the article accepted for publication in Human Rights Quarterly published by John Hopkins University Press: https://www.press.jhu.edu/journals/human rights quarterly/index.html

Accepted version downloaded from SOAS Research Online: http://eprints.soas.ac.uk/23313/

pleasure, while reading aloud, while working, while eating our less than meagre food, and so we go on eking out a bare existence and go on hoping. ${ }^{47}$

Besides the detailed description of abuses and measures taken, Klemperer examined in great detail the racist and dehumanising character of Nazi propaganda and language, and how they were used to change mindsets. In his LTI, which is based on the diaries, Klemperer singles out Strafexpedition (punitive expedition), as the "first term which I recognized as being specifically National Socialist...: For me, the word Strafexpedition was the embodiment of brutal arrogance and contempt for people who are in any way different, it sounded so colonial..."48

Klemperer also commented on how the Nazis increasingly employed the law as an instrument of repression, ${ }^{49}$ and reflected on the modus operandi of the regime:

What I find so much more abominable in all of this than similar things with the Russians: there is nothing spontaneous about it, everything is methodically organised and regulated, it is 'cultivated' cruelty, and it happens hypocritically and mendaciously in the name of culture. No one is murdered here. ${ }^{50}$

He showed how the regime became increasingly brutal, a fact that was becoming more and more apparent, and a matter of public knowledge about atrocities:

[Konrad] believes (to judge by soldiers' reports) that before the retreats everyone was murdered, that we shall see no one again, that six to seven million Jews (of the fifteen million that had existed) have been slaughtered (more exactly: shot and gassed). ${ }^{51}$

In a twist of fate, Klemperer and his wife managed to escape impending death at the hands of the Gestapo or SS (Schutzstaffel) only because of the bombing of Dresden on 13th and 14th 
This is the version of the article accepted for publication in Human Rights Quarterly published by John Hopkins University Press: https://www.press.jhu.edu/journals/human rights quarterly/index.html

Accepted version downloaded from SOAS Research Online: http://eprints.soas.ac.uk/23313/

February 1945. This event sent them on a journey in which they came face to face with war refugees, defeated Germans and the new occupiers. The war was over, and a new chapter opened in Klemperer's eventful life, finding himself "falling between several stools". 52

\section{B. Assessment}

Klemperer's diaries are a highly valuable source that provides a first-hand account of the systematic nature of discrimination and abuse of Jews in Nazi Germany. The diaries combine observation of incidents, patterns and changes, with an analysis of Nazi rule, particularly its use of language. Klemperer showed how the Nazis made a concerted effort to use language in order to influence perceptions and implant concepts and terms into people's minds. ${ }^{53}$ This policy was perniciously effective, as even the opponents of the Nazis, including Klemperer himself, began using Nazi terminology ${ }^{54}$ Klemperer also documented how the Nazis used language both as a form of positive propaganda glorifying Nazism, especially Adolf Hitler, in a quasi-religious fashion, and as a means of justification and denial. The latter analysis is particularly impressive as Klemperer developed a technique of how to read public announcements and reports in the synchronised press to glean the truth. Having no access to other official sources, Klemperer sought to identify contradictions and a change in tone, particularly in war reporting, and succeeded in reading between the lines and making sense of the news. ${ }^{55}$ This technique retains its validity today in situations characterised by government propaganda and censorship, particularly where governments block access to alternative sources of information.

The writing of diaries was not exceptional at the time and not confined to Jews. Jewish diaries have, however, taken on a particular historical significance because of the Holocaust, attracting considerable scholarly interest on the use of diaries as expression of cultural identity, form of resistance and literary genre. ${ }^{56}$ It is useful to conceptualise these diaries not 
This is the version of the article accepted for publication in Human Rights Quarterly published by John Hopkins University Press: https://www.press.jhu.edu/journals/human rights quarterly/index.html

Accepted version downloaded from SOAS Research Online: http://eprints.soas.ac.uk/23313/

so much as daily or regular entries but to view them a "discontinuous series of more or less self-contained responses to the writer's present situation and recent experiencee. ${ }^{57}$ Diaries written by Jews living in Nazi Germany, in the occupied territories or in concentration camps, served multiple purposes, from the personal to the political. They constituted an act of self-preservation and spiritual survival, ${ }^{58}$ a way of recording memory for family members and future generations, and a means of documenting abuses with a view to helping defeat the perpetrators and bringing them to justice. ${ }^{59}$ The urge to bear witness can be understood as a form of resistance. At the personal level, it acts as self-affirmation and narrative that counters attempts to dehumanise and efface the identity of victims. ${ }^{60}$ At the societal level, it helps families and groups to maintain their voice, dignity and strength born out of the knowledge that their suffering is "human" and will eventually be recognised and acknowledged, and their humanity restored. Those who were able to write a diary, or even survived, such as Klemperer, were privileged. The witnesses of the horrors of concentration camps and other violations, whom Primo Levi called the true witnesses, were frequently unable to tell their story. ${ }^{61}$ Klemperer's diaries form part of this broader historical context. He was deeply convinced of the need, and determined, to bear witness, all the while being aware of the personal and collective significance of his endeavour. While he wanted to record the reality of the Third Reich as he experienced it, including its multiple injustices, there is no evidence to suggest that he wrote his diaries for the purpose of their use in holding individuals accountable. ${ }^{62}$ Indeed, the diaries were so personal that Klemperer did not publish them during his lifetime. ${ }^{63}$

Klemperer's diaries are still immensely valuable today, as a meticulous recording of facts and emotions and a close analysis of political and societal developments, as viewed from the particular position in which someone subjected to serious violations finds himself. They 
This is the version of the article accepted for publication in Human Rights Quarterly published by John Hopkins University Press: https://www.press.jhu.edu/journals/human rights quarterly/index.html

Accepted version downloaded from SOAS Research Online: http://eprints.soas.ac.uk/23313/

constitute a form of testimony and self narrative, which escapes the criticism that has been levelled at writing about human rights, particularly human rights reports; they are not abstract and decontextualised, do not 'eradicate subjectivity', ${ }^{64}$ and do not trigger concerns about 'representation', that is the mode of using stories of individual suffering for advocacy purposes. ${ }^{65}$ The medium of a diary raises the question to what degree it can serve as a form of documenting human rights violations. A diary, irrespective of its purpose, constitutes evidence of how its author witnessed and perceived events, which can be of great importance in judicial proceedings or for other bodies, such as truth and reconciliation commissions. ${ }^{66}$ Diaries can also be written deliberately as a means of documenting the reality of daily life, including violations. This form of documentation becomes the more valuable the less other means to document, and to share information, including online, are available. Diary writing therefore retains its importance especially in highly repressive environments. Prison diaries are a case in point, with the Guantanamo diaries written by Mohamedou Ould Slahi being one of the latest diaries of this kind. ${ }^{67}$ This type of diary retains its private character as future publication is uncertain. Other writings called diaries lack the intimacy typically associated with a diary; instead, they serve the function of daily and/or regular eye-witness reporting, particularly in situations where outsiders, such as journalists, have limited access. A recent example is the "Raqqa diaries", chronicling life under the so-called Islamic State. ${ }^{68}$ Beyond providing a factual and subjective account of experiences, diaries occupy a unique space for reflection and analysis. Their personal nature is better suited than general, objective and "neutral" reporting to convey the realities of human rights issues as a context-specific, lived reality. Nonetheless, the two forms of writing are complementary, and indeed many human rights reports include the voice and perspectives of victims. Yet, diaries have a specific quality of speaking to us directly, even years after the event, and this literary quality gives them their capacity to engender understanding, empathy and solidarity with anyone finding 
This is the version of the article accepted for publication in Human Rights Quarterly published by John Hopkins University Press: https://www.press.jhu.edu/journals/human rights quarterly/index.html

Accepted version downloaded from SOAS Research Online: http://eprints.soas.ac.uk/23313/

him-or herself in similar situations. Diaries are therefore part of human rights literature in the broadest sense whose very subjectivity and immediacy may give them a more universal appeal and salience than reports invoking the language of universal rights.

\section{Ernst Fraenkel and Franz Neumann}

Fraenkel and Neumann were the authors of two works about Nazi Germany, which were almost instantly recognised as seminal. A look at their common background shows that the power and impact of their respective work is no coincidence. Rather, it was the outcome of a largely shared, sustained professional and intellectual political struggle. Both Fraenkel and Neumann were labour lawyers during the Weimar republic who, influenced by the work of Hugo Sinzheimer, combined legal practice with theoretical writings and political activism, belonging to the social democrat reformists. In 1927, the two became partners in a law firm, which they ran jointly until 1933. The Nazis coming to power in January 1933 heralded a dual assault on Fraenkel and Neumann as Jewish and social democrat lawyers. Initially, they were able to continue their work, also in the form of secretly documenting abuses. However, on 2 May 1933, their office, located in the trade unions headquarter in Berlin, was raided and attacked. These events set both on different paths, though they remained in sporadic contact thereafter and retained considerable respect for each other's work. ${ }^{69}$ Neumann left Germany after receiving a warning, emigrating first to London before moving to New York. Fraenkel stayed on, continuing his work as a lawyer from home, ${ }^{70}$ and engaging, under a pseudonym, in the political resistance against the Nazis before leaving Germany in $1938 .^{71}$

\section{A. Fraenkel's Dual State}


This is the version of the article accepted for publication in Human Rights Quarterly published by John Hopkins University Press: https://www.press.jhu.edu/journals/human rights quarterly/index.html

Accepted version downloaded from SOAS Research Online: http://eprints.soas.ac.uk/23313/

Fraenkel used the period from 1933-1938 to collect large volumes of materials, including laws, judgments and literature, also drawing on his own work as a lawyer. Experiencing the workings of the Nazi legal system from close quarters, he wanted to develop a theory that enabled him to better understand what he was witnessing. ${ }^{72}$ The result of his work was "The Dual State”. A brief account of its key ideas was published under the pseudonym Conrad Jürges in $1937,^{73}$ with the book first published by Oxford University Press in $1941 .^{74}$

Fraenkel viewed the state of exception, embodied in the Notverordnung (emergency decree) of 28 February 1933, as key to the legal order developed by Nazi Germany. ${ }^{75}$ This order was characterised by the duality of the normative and prerogative state, which was central to Fraenkel's analysis:

By the Prerogative State we mean that governmental system which exercises unlimited arbitrariness and violence unchecked by any legal guarantees, and by the Normative State an administrative body endowed with elaborate powers for safeguarding the legal order as expressed in statutes, decisions of the courts, and activities of the administrative agencies. $^{76}$

Fraenkel stressed, presciently, that "when we speak of the Dual State we do not refer to the co-existence of the state bureaucracy and the party bureaucracy". ${ }^{77}$ Instead, he viewed the duality between prerogative state and dual state as the mode of how the Nazi legal order functions, with the normative state always subject to the encroachments of the prerogative state:

There are no legal rules governing the political sphere. It is regulated by arbitrary measures (Massnahmen), in which the dominant officials exercise their discretionary prerogatives. Hence the expression 'Prerogative State' (Massnahmenstaat). ${ }^{78}$ 
This is the version of the article accepted for publication in Human Rights Quarterly published by John Hopkins University Press: https://www.press.jhu.edu/journals/human rights quarterly/index.html

Accepted version downloaded from SOAS Research Online: http://eprints.soas.ac.uk/23313/

The only limits of the prerogative state, according to Fraenkel, were self-imposed, which means that it retained Kompetenzkompetenz, i.e. was ultimately superior. ${ }^{79}$ The normative state was not an expression of respect for elements of a "Rechtsstaat" (rule of law) but itself part of the political project, ${ }^{80}$ as its confinement to the economic sphere and to politically accepted members of society showed.

The Nazis used the emergency decree of 1933, which remained in force until 1945, as symbolic and practical rejection of the rule of law, and as the basis of their legal revolution which vested Hitler with unlimited powers. ${ }^{81}$ For the Nazis, the function of law was not to protect individual rights or to adhere to formal principles ${ }^{82}$ but to serve "material justice" ${ }^{83}$ Legal principles were not viewed as universal but as expressions of a community, i.e. "the people" ${ }^{84}$ Ultimately, this equated with the Nazi's political project of a collective, "völkische" (people, used in a Nazi racial sense) order in which they appropriated the law by claiming that National Socialism expressed people's justice. ${ }^{85}$

Fraenkel showed in great detail, with reference to numerous cases, the prerogative state in action. Legal principles such as the prohibition of retroactivity, ne bis in idem and proportionality were disregarded ${ }^{86}$ Existing laws did not provide protection; where state or party organs deemed it politically opportune, they ignored or "corrected" judgments or other legal acts. This included cases of threatening individuals with "protective custody", i.e. being taken to a camp and subjected to a regime of ill-treatment, unless they forego their legal claims against the authorities. ${ }^{87}$ Fraenkel recounted a case in which he advised his Jewish client in 1938 not to contest charges of a treacherous attack on the government for having uttered that a report in a Nazi paper is "old hat" 88 and to accept a short prison sentence, instead of risking that the Gestapo will send him to a concentration camp. ${ }^{89}$ There were no effective remedies, even against acts that were clearly unlawful. This applied particularly to 
This is the version of the article accepted for publication in Human Rights Quarterly published by John Hopkins University Press: https://www.press.jhu.edu/journals/human rights quarterly/index.html

Accepted version downloaded from SOAS Research Online: http://eprints.soas.ac.uk/23313/

the Gestapo, whose acts were not subject to judicial review. ${ }^{90}$ As Fraenkel highlighted, the courts themselves repeatedly refused to apply the letter of the law and denied legal protection, invoking the primacy of political considerations and showing deference to the Nazis instead. Courts turned themselves into instruments of the prerogative state by "interpreting" the law in a purely political fashion. ${ }^{91}$ This could go as far as viewing the leisure activities of a catholic youth group as indirect support for the communists. Fraenkel commented that:

This theory of the indirect war on Communism permits the extirpation of any movement which in the slightest sense can be construed as supporting communism. ${ }^{92}$

[and]

No discrimination was made among the various opponents of National-Socialism. They were all labelled Communists. Martial law was applied equally against opponents of the present regime. Through the application of martial law, the National-Socialists obtained a monopoly of power and have maintained it through continuous use. ${ }^{93}$

Fraenkel summed up the "difference between a Rechtsstaat (Rule of Law state) and the Third Reich [as]: in the Rechtsstaat the courts control the executive branch of the government in the interest of legality. In the Third Reich the police power controls the courts in the interests of political expediency." ${ }^{94}$ Significantly,

Politics is that which political authorities choose to define as political. The classification of an action as political or non-political determines whether it will be dealt with according to law or according to the arbitrary preferences of the political authorities. The legal system of present day Germany is characterized by the fact that there are no matters safe 
This is the version of the article accepted for publication in Human Rights Quarterly published by John Hopkins University Press: https://www.press.jhu.edu/journals/human rights quarterly/index.html

Accepted version downloaded from SOAS Research Online: http://eprints.soas.ac.uk/23313/

from the intervention of the political authorities who, without any legal guarantees, are free to exercise discretion for political ends. ${ }^{95}$

For Fraenkel, the main rationale of the normative state was to maintain a legal system that was required for the functioning of capitalism. This included "freedom of enterprise, sanctity of contracts, private property, the right of the entrepreneur to control labour, regulation of unfair competition, regulation of patent, trade-mark rights, etc., legal protection for interest agreements, property and transfer for purposes of security". ${ }^{96}$ A series of judgments illustrated how courts upheld legal principles in the sphere of commercial law. ${ }^{97}$ The normative state itself, however, was subject to considerations of race and class. Jews were denied any legal protection, which was reserved for what the regime called "constructive forces of the nation". ${ }^{98}$ Workers were denied any independent representation, as trade unions were banned, and labour rights. ${ }^{99}$ The latter was part of the regime's economic policy, aimed at establishing its political-economic power, increasing employment and occupation, and sectoral reforms. ${ }^{100}$ The economic policy served the interests of monopoly capitalism and was closely linked to nationalist and imperialist ambitions, including the military complex. ${ }^{101}$

Fraenkel's Dual State was instantly recognised as a highly valuable analysis of Nazi Germany, particularly its legal order, and remains the only such work based on detailed empirical research that was carried out in Germany after 1933, and published at the time when the Nazis were still in power. It was widely reviewed in the Anglo-American world, largely favourably, and continues to be viewed by historians as the key work on the Nazi legal order. ${ }^{102}$ Its analysis has therefore stood the test of time, with the qualification that Fraenkel paid limited attention to laws that embodied injustice, such as racial discrimination laws. $^{103}$

\section{B. Neumann's Behemoth}


This is the version of the article accepted for publication in Human Rights Quarterly published by John Hopkins University Press: https://www.press.jhu.edu/journals/human rights quarterly/index.html

Accepted version downloaded from SOAS Research Online: http://eprints.soas.ac.uk/23313/

Neumann wrote the Behemoth, subtitled: The Structure and Practice of National Socialism, 1933-1944, over a period of two years at his time during the Institute of Social Research. The book, published in 1942 (second edition in 1944), is a wide ranging analysis of politics, economy, law and society of Nazi Germany. It was based on a close reading of Nazi literature and materials, including official publications and newspaper reports, which Neumann analysed with reference to the history of Germany's political thought and developments. His ostensible goal was to shed light on the underlying structure and dynamics of Nazi rule, with reference to examples of how it operated, and to refute what he viewed as misconceptions about its true nature.

Neumann argued that Nazi Germany lacks any clear ideology or structure, and is ultimately based on propaganda and violence:

In its external form as propaganda, totalitarian ideology differs from democratic ideologies not only because it is single and exclusive, but because it is fused with terror... . The democratic ideology is successful if it can persuade or attract; the National Socialist ideology persuades through its use of terror. ${ }^{104}$

Having thrived and capitalised on the structural deficits of Weimar Germany, Nazi rule was based on the role of a charismatic leader and the primacy of the political. Neumann showed how the Nazis, while initially endorsing it, later rejected the notion of a "totalitarian state", as "the doctrine of state supremacy had to be abandoned in Germany because claims of the party conflicted with the claims of the state." 105 In contrast to state-centric Italian fascism, this situation created theoretical and practical problems, leaving Neumann to conclude that "the state and the party stand side by side. Legally neither controls the other, each is sovereign in its own field- a constitutional situation which is self-contradictory."106 
This is the version of the article accepted for publication in Human Rights Quarterly published by John Hopkins University Press: https://www.press.jhu.edu/journals/human rights quarterly/index.html

Accepted version downloaded from SOAS Research Online: http://eprints.soas.ac.uk/23313/

Domestic policy combined anti-semitism in pursuit of the friend-foe distinction ${ }^{107}$ and as scapegoating device, with the subjugation and control of the individual in the name of the people. Anti-semitism was a natural expression of racism in Germany, as it "had deep roots in German history". ${ }^{108}$ However, "National Socialism is the first Anti-Semitic movement to advocate the complete destruction of the Jews." ${ }^{109}$ In examining anti-Jewish legislation, Neumann commented on the difference between "National Socialism and bolshevism". ${ }^{110}$ It is " $[\mathrm{n}]$ ot the persecution of political opponents - which is practiced in both countries - but the extermination of helpless individuals [that] is the prerogative of National Socialism."111 The policy of eliminating "Jews from economic life was carried out in three forms: contractually, illegally, and by statute". ${ }^{112}$ Its purpose was to redistribute "property among those strata of the population whose support is vital for the regime: the powerful financial and industrial capitalists" and to satisfy "the anti-capitalist longings of the Germany people". ${ }^{113}$ The political function of the "present all-pervading Anti-Semitism" was to act as "substitute[] for the class struggle ... [to] provide[] a justification for eastern expansion ... [and as] an expression of the rejection of Christianity and all it stands for". ${ }^{114}$

For Neumann, an understanding of the close relationship between the Nazi party and monopoly capitalism was key to grasping the political and economic nature of the state, and its business policy:

The German economy of today has two broad and striking characteristics. It is a monopolist economy - and a command economy. It is a private capitalist economy, regimented by the totalitarian state. We suggest as a name best to describe it, 'Totalitarian Monopoly Capitalism. ${ }^{, 115}$ 
This is the version of the article accepted for publication in Human Rights Quarterly published by John Hopkins University Press: https://www.press.jhu.edu/journals/human rights quarterly/index.html

Accepted version downloaded from SOAS Research Online: http://eprints.soas.ac.uk/23313/

Protecting the interests of monopoly capitalism, as well as of the bureaucracy, was crucial, particular at the early period of Nazi rule to ensure that " $[\mathrm{t}]$ he revolution was to proceed in an orderly fashion..."116 For example,

Dr. Frick [the then Minister of the Interior] warn[ed] high federal officials ... against allowing the party machine to infringe upon the authority of the bureaucracy. Dr. Frick had no intention of interfering with the terrorization of Jews; the beating of defenceless prisoners in the Brown shirt barracks; the kidnapping of communists, socialists, and pacifists; or the murder-'shot while trying to escape'-of political enemies. But the party must not interfere in business and administration. ${ }^{117}$

However, as Neumann showed, the government did intervene, by pursuing economic policies that benefited big industrial business, leading to a situation where profit motives and the demands of economic recovery and a war economy met. ${ }^{118}$

Nazi foreign policy was based on notions of racial imperialism, with the ideology of expansion based on "tradition, geopolitics, and pro-natalism" as well as "a new international law". ${ }^{119}$ Neumann demonstrated step-by-step how racial theory removed legal limits on state sovereignty in positive international law, to serve expansionist interests:

(1) By denying that states are subjects of international law, it denies the equality of all states and allows differentiation among them. (2) By denying that states have sovereignty, it destroys the last elements of rationality in international relations. The spatial and functional limits inherent in the notion of state sovereignty disappear. (3) By proclaiming the sovereignty of the race, it subjects all racial Germans, whatever their nationality, to the law of the Germanic race. (4) By denying that international law exists among rival empires, it rejects any legal frontier to aggression, while at the same time it defends its 
This is the version of the article accepted for publication in Human Rights Quarterly published by John Hopkins University Press: https://www.press.jhu.edu/journals/human rights quarterly/index.html

Accepted version downloaded from SOAS Research Online: http://eprints.soas.ac.uk/23313/

own empire by a perverted Monroe Doctrine. (5) By applying the term international law to the relations between the folk groups within its empire, it destroys the last remnants of minority protection and invests minority oppression with the sanctity of international law. ${ }^{120}$

Contrary to claims that Nazi Germany had become classless, its social policy, according to Neumann,

consists in the acceptance and strengthening of the prevailing class character of its ruling class, in the atomization of the subordinate strata through the destruction of every autonomous group mediating between them and the state, in the creation of the system of autocratic bureaucracies interfering in all human relations. The process of atomization extends even to the ruling class in part. It goes hand in hand with a process of differentiation within the mass party and within society that creates reliable élites, the regime plays off one group against the other and enables a minority to terrorize the majority. $^{121}$

After careful examination of theories of the state, Neumann concluded that Nazi Germany is a non-state, "in which the ruling groups control the rest of the population directly, without the mediation of that rational through coercive apparatus hitherto known as the state."122 It was characterised by what has been called "totalitarian pluralism". ${ }^{123}$ This consisted of the NSDAP, a "machine" and "huge bureaucracy", ${ }^{124}$ the army, monopoly capitalism, and bureaucracy (largely conservatively minded civil servants) operating as parallel, and at times competing centres of power.

In this totalitarian pluralism, the ruling class “ $\ldots$ is far from homogenous. There are as many interests as there are groups. Nothing holds them together but the reign of terror and their fear 
This is the version of the article accepted for publication in Human Rights Quarterly published by John Hopkins University Press: https://www.press.jhu.edu/journals/human rights quarterly/index.html

Accepted version downloaded from SOAS Research Online: http://eprints.soas.ac.uk/23313/

least the collapse of the regime destroys them all." 125 Totalitarian pluralism was therefore both intensely powerful and fragile:

Nothing remains but profits, power, prestige, and above all, fear. Devoid of any common loyalty and concerned solely with the preservation of their own interests, the ruling groups will break as soon as the miracle-producing Leader meets a worthy opponent. At present, each section needs the others. The army needs the party because the war is totalitarian. The army cannot organize society 'totally'; that is left to the party. The party, on the other hand, needs the army to win the war and thus stabilize and even aggrandize its own power. Both need monopolistic industry to guarantee continuous expansion. And all three need the bureaucracy to achieve the technical rationality without which the system could not operate. Each group is sovereign and authoritarian; each is equipped with legislative, administrative, and judicial power of its own; each is thus capable of carrying out swiftly and ruthlessly the necessary compromises among the four. ${ }^{126}$

In contrast to the ruling class, the ruled class was subject to "monistic, total, authoritarian organization" as the Nazis had "no faith in society". ${ }^{127}$ Individuals were atomized and natural relations broken up, with the aim of driving people into collective bodies. ${ }^{128}$ Neumann demonstrated in great detail how independent institutions and the workers' movement in particular had been destroyed, with the regime's success coming at the expense of the enjoyment of labour rights. Propaganda was insufficient to maintain such a system, and was therefore "supplemented by terror. Violence is not just one important phenomenon in the structure of National Socialist society; it is the very basis upon which the society rests. Violence not only terrorizes but attracts."129

In his analysis of Nationalist Socialist law, Neumann posited a theory of law that stresses its general character and formal structure. It is " $[\mathrm{t}]$ he generality and the abstractness of law 
This is the version of the article accepted for publication in Human Rights Quarterly published by John Hopkins University Press: https://www.press.jhu.edu/journals/human rights quarterly/index.html

Accepted version downloaded from SOAS Research Online: http://eprints.soas.ac.uk/23313/

together with the independence of the judge [that] guarantee a minimum of personal and political liberty." ${ }^{130}$ National Socialism relied on "legal standards of conduct" rather than "legal rules" and thereby "completely destroys the generality of the law and with it the independence of the judiciary and the prohibition of retroactivity." ${ }^{\prime 131}$ This introduced political elements which reduced the judge "to the status of a police official." "132 Law became "the mere command of the sovereign", being based on decisionism, ${ }^{133}$ and "a means for the stabilization of power". ${ }^{134}$ This entailed a lack of separation of powers, with "[t]he authority of the judge ... rest[ing] upon the pronouncements of the Leader." ${ }^{135}$ The lack of legal protection was reflected in legislation such as the Prussian decree of 10 February 1936, which had given the Gestapo "absolute and arbitrary power ... over all personal liberties...."136 Neumann concluded his extensive review of the legal system, in which he explicitly rejected Fraenkel's notion of the dual state ${ }^{137}$ with the following answer to his rhetorical question: "Does such a system deserve the name of law?"

Yes, if law is merely the will of the sovereign; definitely not, if law, unlike the sovereign's command, must be rational either in form or in content. The National Socialist legal system is nothing but a technique of mass manipulation by terror. Criminal courts, together with the Gestapo, the public prosecutor, and the executioners, are now primarily practitioners of violence. Civil courts are primarily agents of the commands of monopolistic business organizations. ${ }^{138}$

This difference in view between Neumann and Fraenkel has been attributed to the time of writing of the two books (with the initial dual state later replaced by complete lawlessness) but it is also clear that the two used different understandings of law, which explains their divergent conclusions in this regard. ${ }^{139}$ 
This is the version of the article accepted for publication in Human Rights Quarterly published by John Hopkins University Press: https://www.press.jhu.edu/journals/human rights quarterly/index.html

Accepted version downloaded from SOAS Research Online: http://eprints.soas.ac.uk/23313/

The Behemoth was hailed as the most important analysis of Nazi Germany. It has been called "one of the classics of modern political analysis" $" 140$ and remains central to an understanding of the history of Nazi Germany. ${ }^{141}$ Neumann's analysis, also as a result of his work in the Office of Strategic Service from 1943 to 1945, had a practical bearing on the objectives of US post war policy, which focused on denazification, democratisation, demilitarisation, and decartelisation. ${ }^{142}$ Neumann's imprint was also visible in the Nuremberg trials (he was a member of the prosecution team). ${ }^{143}$ In the collection of evidence, "relevant papers were sorted among four groups, each with a distinct prefix that referred to one of Neumann's quadrumvirate of power structures $(\mathrm{NO}=$ Nazi organization, that is, the party; $\mathrm{NG}=\mathrm{Nazi}$ government; NOKW = Nazi Military High Command; and NI = Nazi industry)."

\section{Assessment of Fraenkel's and Neumann's work}

The detailed scrutiny of the workings of National Socialism enabled Fraenkel and Neumann to develop theories, of the dual state and totalitarian pluralism respectively, which provided the intellectual tools for their incisive analysis. This analysis, informed by their own experiences and close study of primary sources, exposed the nature and structure of power, how it functioned in practice, and whose interests it served. Fraenkel's and Neumann's books, as well as other works published by both authors at the time, ${ }^{145}$ formed an integral part of the political resistance against Nazi Germany. By the time of their publication, both authors were in exile, and both books were clearly aimed at an Anglo-American audience. Their goal was to support the war effort and to influence both responses to Nazi Germany and plans for post-war policies, including in relation to criminal accountability and reconstruction. The reception of their work at the time suggests that it was highly influential in shaping understanding of the nature of Nazi Germany, even though its actual influence on policy making appears to have been limited. ${ }^{146}$ 
This is the version of the article accepted for publication in Human Rights Quarterly published by John Hopkins University Press: https://www.press.jhu.edu/journals/human rights quarterly/index.html

Accepted version downloaded from SOAS Research Online: http://eprints.soas.ac.uk/23313/

Fraenkel's and Neumann's work holds critical lessons going beyond its time. Having experienced the defeat of a (flawed) order they had fought for (the Weimar Republic), and having experienced discrimination and violations first hand, both men used their intellect as weapons to fight back against a regime that had come to embody the antithesis of the rule of law. Both books are examples of engaged scholarship based on rigorous research and analysis. They, especially Neumann’s work, draw on a range of disciplines, particularly law, political theory and economics, which accounts for their breadth. ${ }^{147}$ Their structural analysis, ${ }^{148}$ which identified underlying material factors and "root causes", and functional analysis of how the system operated opened an unrivalled contextual understanding of a regime whose nature was subject to misconceptions at the time.

Their approach remains pertinent today when considering, in any given system, the relationship between law and power, and the role of economic factors. It provides tools to gain a better understanding of the power structures of regimes and of how legal systems and institutions function to advance certain interests, including by establishing regimes of legalised terror. Iraq under Saddam Hussein, Libya under Ghaddafi, and North Korea are cases in point. ${ }^{149}$ South Africa under apartheid is an example of a state which combined elements of the formal and the prerogative state. ${ }^{150}$ A number of other regimes have ruled on the basis of states of exception, often for decades, which have undermined legal protection, while at the same time maintaining a formal system in the economic sphere, also in line with neo-liberal orthodoxies. ${ }^{151}$ Security legislation frequently resembles aspects of the Gestapo law, reflecting the power (often political and economic) of security agencies and the military that are beyond the reach of courts. ${ }^{152}$ The risk to the rule of law inherent in creating special regimes for "enemies" based on political considerations has come to be embodied in Guantánamo Bay. The developments post 9/11 triggered a revival of interest in Carl 
This is the version of the article accepted for publication in Human Rights Quarterly published by John Hopkins University Press: https://www.press.jhu.edu/journals/human rights quarterly/index.html

Accepted version downloaded from SOAS Research Online: http://eprints.soas.ac.uk/23313/

Schmitt's ideas of a powerful state unrestrained by liberal laws, ${ }^{153}$ which Fraenkel and Neumann repeatedly criticised. The potential that notions of material justice based on exclusionary communal notions (whether they rest on class, religion, ethnicity or other factors) result in, or justify violations of individual rights has also been evident. ${ }^{154}$ However, as Fraenkel emphasised, his analysis was confined to Nazi Germany, ${ }^{155}$ and the nature of other regimes would need to be examined carefully. This is an important caveat, which points to a crucial aspect of Fraenkel's work. It was empirical, and combined legal with political and sociological observations, seeking to develop a theory that explained the practice he knew and was confronted with.

Fraenkel's and Neumann's mode of analysis and theories also have wider application. They are particularly useful when considering how, and for whose benefit, states and other entities, such as multinational corporations, use the law, and what impact this has on those denied the protection of law. ${ }^{156}$ Such an understanding can have important strategic value for human rights actors in terms of how to frame advocacy, whom to target, and what action to propose in response. It calls for a nuanced and contextualised approach to entities such as "the state" and how to engage with them, in so far as, and to the extent that it is possible, or to de- and re-construct them, where necessary.

\section{Conclusion}

Klemperer, Fraenkel and Neumann are powerful voices of individuals who experienced systematic discrimination on account of being Jewish, and, in the case of Fraenkel and Neumann, their political work. All three used the intellectual means at their disposal to resist the Nazis; Klemperer primarily analysing language, Fraenkel and Neumann the legal and political system. All three benefited from having lived in a system, which, however flawed, had guaranteed a measure of intellectual freedom and legal protection. This, together with 
This is the version of the article accepted for publication in Human Rights Quarterly published by John Hopkins University Press: https://www.press.jhu.edu/journals/human rights quarterly/index.html

Accepted version downloaded from SOAS Research Online: http://eprints.soas.ac.uk/23313/

their education and rootedness in what may, at the risk of simplification, be broadly termed enlightenment thought (Klemperer) and socialist thought (Fraenkel and Neumann), served as counterweight that gave strength to their convictions and analysis. One of the most striking aspects of the work of "leftist" Fraenkel and Neumann was their spirited defence of the rule of law. They acknowledged the problems faced by the liberal order and rule of law in Weimar Germany but, instead of replacing it altogether, called for the state and the law to be anchored in a socialist order. Neumann defended the notion of general, formal law as important constraint and protection against an order ultimately based on political and economic prerogatives of those in a position of power. ${ }^{157}$ It was clear to him, Fraenkel, and others, such as Otto Kirchheimer, ${ }^{158}$ that the erosion if not destruction of formal law, and legal protection, would open the door to justify discrimination and abuses, whatever theory or ideology is drawn upon to legitimise an alternative, material order. As Scheuerman points out:

Neumann and Kirchheimer present an impressive challenge to the knee-jerk hostility to liberal legalism widespread in contemporary critical legal scholarship. Witnesses to the tragic destruction of the Weimar Republic and the rise of Nazism, Neumann and Kirchheimer argued early on that crucial components of the rule of law are threatened in the twentieth century by a series of unprecedented political and social transformations..... 159

Neumann applied this equally to international law:

To abandon universalism because of its failures is like rejecting civil rights because they help legitimize and veil class exploitation, or democracy because it conceals boss control, or Christianity because churches have corrupted Christian morals. Faced with a corrupt administration of justice, the reasonable person does not demand a return to the war of 
This is the version of the article accepted for publication in Human Rights Quarterly published by John Hopkins University Press: https://www.press.jhu.edu/journals/human rights quarterly/index.html

Accepted version downloaded from SOAS Research Online: http://eprints.soas.ac.uk/23313/

each against all, but fights for an honest system. Likewise, when we have shown that international law has been misused for imperialistic aims, our task has begun, not ended. We must fight against imperialism. ${ }^{160}$

These words strongly resonate today, stressing the importance of rights, democracy and international solidarity in the fight against myriad forms of injustice. A critical awareness of the challenges inherent in these notions is an integral part of this struggle, and not a reason to abandon them altogether, thereby risk leaving the ground to their enemies. Such awareness plays an important role, warding off any portrayal of human rights actors as being at best naïve or at worst cheerleaders for a neo-imperial world order.

The account of Klemperer's, Fraenkel's and Neumann's work does not suggest that their analysis was either representative (of Jews, socialists) or flawless. It reflects their political orientation as well as social positions and experiences as largely or fully assimilated, middleclass (broadly speaking) Jews in Germany at the time. As males, and in tune with their time, a gender analysis of Nazi Germany is notably absent. ${ }^{161}$ These qualifications notwithstanding, their legacy transcends their historical context. They are impressive figures in a long line of women and men who have used the power of thought and language to fight injustice and to advocate for an alternative that takes suffering and rights seriously. ${ }^{162}$ Their work underscores the power of documentation and analysis as praxis of resistance, as construction of alternative political models, and as memory and education. Their engagement, though originating in a very different context, carries a number of important lessons for today's human rights practice. It can be translated as a call from the past to be rigorous in analysing how a regime or system operates and how it impacts individuals, institutions and society at large. This requires paying close attention to language and documents, i.e. to take the outputs of a regime seriously, so as to identify its underlying ideology and motivations. It also 
This is the version of the article accepted for publication in Human Rights Quarterly published by John Hopkins University Press: https://www.press.jhu.edu/journals/human rights quarterly/index.html

Accepted version downloaded from SOAS Research Online: http://eprints.soas.ac.uk/23313/

includes a focus on understanding the political, social and economic logic of a system.

Drawing on multiple disciplines when analysing causes and enabling factors of violations and developing theories that help explain the realities of a regime or system are critical to unmask their underlying ideology and better grasp their modus operandi. Using these findings in public debate and in other channels is part of broader struggles to challenge and defeat a rights-violating regime, or change a rights-violating system, and to set out alternative approaches that help rebuild societies by providing them with a political and moral compass.

Fraenkel and Neumann, and Klemperer to some extent, did this for Germany, though their contribution was only recognised belatedly. It is now time that their contribution to the rule of law and human rights engagement more broadly is fully appreciated, as they have a lot to offer, having fought with all their intellectual might against a regime whose abomination provided the impetus for today's system of international human rights protection. 
This is the version of the article accepted for publication in Human Rights Quarterly published by John Hopkins University Press: https://www.press.jhu.edu/journals/human rights quarterly/index.html

Accepted version downloaded from SOAS Research Online: http://eprints.soas.ac.uk/23313/

${ }^{1}$ Richard Wilson, Representing Human Rights Violations: Social Contexts and Subjectivities, in HUMAN RIGHTS, CULTURE AND CONTEXT: ANTHROPOLOGICAL PERSPECTIVES 134-60, 148 (R. Wilson, ed., 1997).

${ }^{2}$ Susan Marks, Human Rights and Root Causes, 74 Mod. L. Rev. 57, 75 (2011).

${ }^{3}$ Ibid.

${ }^{4}$ David Kennedy, The International Human Rights Movement: Part of the Problem, 15 Harv. Hum. Rts. J. 101, 108-10 (2002).

5 Id., 119-21.

${ }^{6} I d ., 124-5$.

${ }^{7}$ See for example Nikolaus Wachsmann, KL: A HISTORY OF THE NAZI CONCENTRATION CAMPS 6473, 528-30 (2015).

${ }^{8}$ Nazi crimes spawned multiple efforts, by both activists and officials, to document acts that were (later to be) recognised as crimes against peace, war crimes, crimes against humanity and genocide. See in particular Symposium: The United Nations War Crimes Commission and the Origins of International Criminal Justice, 25 Crim. L. Forum (2014) (1-2).

${ }^{9}$ See further Margaret E. Keck and Kathryn Sikkink, ACTIVISTS BEYOND BORDERS: ADVOCACY NETWORKS IN INTERNATIONAL POLITICS (1998); Thomas Risse, Stephen C. Ropp and Kathryn Sikkink (eds.), THE PERSISTENT POWER OF HUMAN RIGHTS: FROM COMMITMENT TO COMPLIANCE (2013).

${ }^{10}$ See on the notion of being "rightless", Hannah Arendt, THE ORIGINS OF TOTALITARIANISM, New Edition 267-302 (1973).

${ }^{11}$ Klemperer was born on 9 October 1881, Fraenkel, on 26 December 1898, and Neumann, on 23 May 1900.

${ }^{12}$ Victor Klemperer, I SHALL BEAR WITNESS: THE DIARIES 1933-1941 (1999); TO THE BITTER END, THE DIARIES OF VICTOR KLEMPERER 1942-1945 (1995).

${ }^{13}$ See on writings, particularly diaries, by victims (those who died) and survivors, in particular Alexandra Gabarini, NUMBERED DAYS: DIARIES AND THE HOLOCAUST (2006); Giorgio Agamben, REMNANTS OF AUSCHWITZ: THE WITNESS AND THE ARCHIVE (2002); Alexandra Zapruder, SALVAGED PAGES: YOUNG WRITERS' DIARIES OF THE HOLOCAUST, Second Edition (2015). See for two powerful accounts by Holocaust survivors, Primo Levi, IF THIS IS A MAN (1959), and Jean Amery, AT THE MIND'S LIMITS: CONTEMPLATIONS BY A SURVIVOR OF AUSCHWITZ AND ITS REALITIES (1980).

${ }^{14}$ See on the Frankfurt School during this period, Barry M. Kätz, The Criticism of Arms: The Frankfurt School goes to war, 59 J. Mod. Hist., 439 (1987), and, on Neumann's time at the Frankfurt School, Rainer Erd (ed.), REFORM UND RESIGNATION, GESPRÄCHE ÜBER FRANZ L. NEUMANN 83-150 (1985).

${ }^{15}$ The book was published in English in 1941. The German version was first published in 1974, Ernst Fraenkel, DER DOPPELSTAAT (1974).

${ }^{16}$ Franz Neumann, BEHEMOTH (1992) and the new edition, BEHEMOTH, THE STRUCTURE AND

PRACTICE OF NATIONAL SOCIALISM, 1933-1944 (1944) (citations in this article refer to the 2009 reprint with an introduction by Peter Hayes).

${ }^{17}$ Alexander v. Brünneck, in his introduction to Fraenkel's Doppelstaat, mentions 13 reviews of Fraenkel's work, see Ernst Fraenkel, DER DOPPELSTAAT, Third Edition, 14, fn. 20 (2012). A jstor search for Neumann's Behemoth showed 15 reviews from 1942-1945.

${ }^{18}$ This article focuses on Fraenkel's Dual State and Neumann's Behemoth, and does therefore not consider their work after 1945. See for a list of Fraenkel's work and a detailed bibliography, Simone Ladwig-Winters, ERNST FRAENKEL: EIN POLITISCHES LEBEN 415-439 (2009). On Neumann, see his essays in THE RULE OF LAW UNDER SIEGE: SELECTED ESSAYS OF FRANZ L. NEUMANN AND OTTO KIRCHHEIMER 195242 (William Scheuerman ed.,1996), and Erd, supra note 14, 239-52, 262.

${ }^{19}$ Douglas G. Morris, Discrimination, Degradation, Defiance: Jewish Lawyers under Nazism, in THE LAW IN NAZI GERMANY: IDEOLOGY, OPPORTUNISM, AND THE PERVERSION OF JUSTICE 105-135 (Alan E. Steinweis \& Robert D. Rachlin eds., 2015).

${ }^{20}$ See Kätz, supra note 14, and Erd, supra note 14. On Fraenkel's time and influence in the US from 1938-1945, see Ladwig-Winters, supra note 18, 129-209.

${ }^{21}$ William E. Scheuerman, BETWEEN THE NORM AND THE EXCEPTION: THE FRANKFURT SCHOOL AND THE RULE OF LAW (1994), and Douglas C. Morris, Write and Resist: Ernst Fraenkel and Franz Neumann on the Role of Natural Law in Fighting Nazi Tyranny, 126 New Ger Crit. 197 (2015).

${ }^{22}$ Morris, id.

${ }^{23}$ Jens Meierhenrich, THE LEGACIES OF LAW: LONG-RUN CONSEQUENCES OF LEGAL DEVELOPMENT IN SOUTH AFRICA, 1652-2000 (2008).

${ }^{24}$ William E. Scheuerman, Franz Neumann - Legal Theorist of Globalization? 8 Constellations 503 (2001). 
This is the version of the article accepted for publication in Human Rights Quarterly published by John Hopkins University Press: https://www.press.jhu.edu/journals/human rights quarterly/index.html

Accepted version downloaded from SOAS Research Online: http://eprints.soas.ac.uk/23313/

${ }^{25}$ Victor Klemperer, THE LANGUAGE OF THE THIRD REICH: LTI-LINGUA TERTII IMPERII, A

PHILOLOGIST'S NOTEBOOK (2000) (originally published in German, 1947).

${ }^{26}$ Klemperer was a War veteran and married to an 'Aryan' German, which provided him with a (precarious) measure of protection, see further Marion A. Kaplan, BETWEEN DIGNITY AND DESPAIR: JEWISH LIFE

IN NAZI GERMANY 74-93 (1998). Klemperer is frequently used as a source in books on the Third Reich, see e.g. Saul Friedländer, NAZI GERMANY AND THE JEWS, VOLUME 1: THE YEARS OF PERSECUTION, 1933-1939 (1997) and THE YEARS OF EXTERMINATION: NAZI GERMANY AND THE JEWS, 19391945 (2007), particularly at 63-4 and 662-3, on Jewish diarists and their fate during the war.

${ }^{27}$ See on Klemperer's LTI in particular Jens Meierhenrich, The Language of Klemperer in EVOKING GENOCIDE: SCHOLARS AND ACTIVISTS DESCRIBE THE WORKS THAT SHAPED THEIR LIVES 122-8 (Adam Jones ed., 2009).

${ }^{28}$ See e.g. Costas Douzinas, THE END OF HUMAN RIGHTS: CRITICAL LEGAL THOUGHT AT THE TURN OF THE CENTURY (2000); Stephen Hopgood, THE ENDTIMES OF HUMAN RIGHTS (2013); Eric Posner, THE TWILIGHT OF HUMAN RIGHTS LAW (2014).

${ }^{29}$ See supra note 25 , and, further, Peter Jacobs, VICTOR KLEMPERER: IM KERN EIN DEUTSCHES GEWÄCHS, EINE BIOGRAPHIE, Third Edition (2010).

${ }^{30}$ See Henry Ashby Turner Jr., Victor Klemperer's Holocaust, 22 Ger. Std. Rev. 385, 385 (1999), and, further, contributions in Hannes Heer (ed.), IM HERZEN DER FINSTERNIS: VICTOR KLEMPERER ALS CHRONIST DER NS-ZEIT (1997).

${ }^{31}$ See for example the materials listed on the website of the German Federal Agency for Civic Education, www.bpb.de.

32 Victor Klemperer, ICH WILL ZEUGNIS ABLEGEN BIS ZUM LETZTEN: TAGEBÜCHER 1933-1941 [1]; 1942-1945 [2], 9 th edn. (1997). A CD-Rom published in German in 2007 contains the full book of over 5,000 pages.

${ }^{33}$ Roger Woods, The Referential and the Relational: Victor Klemperer's Diaries in the Nazi Years, 7 JWCS, 336 (2014).

${ }^{34}$ Both publicly by virtue of the degrading measures that Jews were exposed to, and personally as diminished self-respect.

${ }^{35}$ Klemperer's wife Eva would take the diaries to a friend, Annemarie Köhler, first in Heidenau, then in Pirna, putting themselves as well as those named therein at great risk, Klemperer, BITTER END, supra note 12, 445 (27 September 1944).

${ }^{36} I d ., 376$ (8 April 1944).

${ }^{37}$ Id., 376-7.

${ }^{38} I d ., 377$.

${ }^{39}$ Klemperer, WITNESS, supra note 14, 18 (25 April 1933).

${ }^{40} I d$., 231 (14 September 1936).

${ }^{41}$ Id., 353 (10 January 1939).

${ }^{42}$ Id., 529-30 (18-20 September 1941).

${ }^{43} I d$., 476-509 (23 June - 1 July 1941).

${ }^{44}$ Klemperer, BITTER END, supra note 14, 279 (11 May 1943).

${ }^{45}$ Id., 34 (16 March 1942). However, see Turner, supra note 30, 392-4, for an analysis of Klemperer's incomplete knowledge about the genocide.

${ }^{46}$ Klemperer, BITTER END, supra note 14, 222 (31 December 1942).

${ }^{47} I d ., 77$ (30 May 1942).

${ }^{48}$ Klemperer, LTI, supra note 25, 39.

${ }^{49}$ See perceptive comments in his entries dated 7 March 1942 (Klemperer, ZEUGNIS 1942-1945, supra note 32,40 ) on the conflation of people's law with the party claiming to represent the people, and on "Thierack, the former Saxon Justice Minister - well known as a bloodhound - was announced as Reich Minster of Justice on $20^{\text {th }}$ August. The decree says his task is to 'establish a National Socialist administration of justice': 'In doing so he can deviate from existing law'," Klemperer, BITTER END, supra note 14, 163 (29 August 1942) (emphasis in original).

${ }^{50}$ Id., 148 (14 August 1942).

${ }^{51}$ Id., 454 (24 October 1944).

${ }^{52}$ Literal translation of the German version. See, in English, THE DIARIES OF VICTOR KLEMPERER 194559: THE LESSER EVIL (2003).

${ }^{53}$ See for a brief analysis, Meierhenrich, Klemperer, supra note 27, who discusses the use of the words Volk (people), organisieren (to organise) and Erlebnis (experience), quoting, at 125, from Klemperer's LTI: "Emotion had to suppress the intellect and itself surrender to a state of numbing dullness without any freedom of will or 
This is the version of the article accepted for publication in Human Rights Quarterly published by John Hopkins University Press: https://www.press.jhu.edu/journals/human rights quarterly/index.html

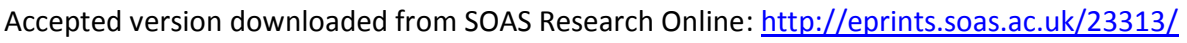

feeling: how else would one have got hold of the necessary crowd of executioners and torturers? What does a perfect group of followers do? It doesn't think, and it doesn't even feel any more -it follows."

${ }^{54}$ See e.g. 6 February 1944 (Klemperer, ZEUGNIS, supra note 32), 483.

${ }^{55}$ See reflections in Klemperer, LTI, supra note 25, 8-14.

${ }^{56}$ Gabarini, supra note 13 .

${ }^{57}$ Id., 17.

${ }^{58}$ And identity formation in extraordinary times, see Anne Frank, THE DIARY OF A YOUNG GIRL (1952).

${ }^{59}$ Gabarini, supra note 13, 17-9.

${ }^{60}$ See Diana Tietjens Meyers, VICTIMS' STORIES AND ADVANCEMENT OF HUMAN RIGHTS 5-16

(2016), on this point when discussing Slahi's Guantanamo Diaries, and, with reference to testimonies, Nora Strejilevich, Testimony: Beyond the Language of Truth, 28 Hum. Rts. Q. 701, 706 (2006): "truth told in testimony, even if it cannot stop the reiteration of such crimes, is one of the reservoirs of dignity left for humanity".

${ }^{61}$ See quote in Agamben, supra note 13, 34, with further discussion.

${ }^{62}$ See, however, on Johannes Clemens who Klemperer had identified by name in his diaries as a particularly brutal and notorious Gestapo man, Wolfgang Kraushaar, Karriere eines Boxers: Johannes Clemens: Vom Dresdner Gestapo-Schläger zum Doppelagenten des KGB im BND, in Heer, supra note 30, 152-69. (which translates as Career of a boxer: Johannes Clemens: From Dresden's Gestapo thug to KGB double agent working for the BND (German intelligence services)).

${ }^{63}$ See Klemper, LTI, supra note 25, 9. See on the history of the diaries, Susanne zur Nieden, Aus dem vergessenen Alltag der Tyrannei: Die Aufzeichnungen Victor Klemperers im Vergleich zur zeitgenössischen Tagebuchliteratur in Heer, supra note 30, 110-21.

${ }^{64}$ Wilson, supra note 1, 134-60.

${ }^{65}$ Ian Patel, The Role of Testimony and Testimonial Analysis in Human Rights Advocacy and Research, 1 St. Crim. J. 235 (2012), and Kerry Bystrom, Literature and Human Rights in HANDBOOK OF HUMAN RIGHTS 637-46 (Thomas Cushman ed., 2012).

${ }^{66}$ See for a discussion of "narrative truth", Willie Henderson, Review Article: Metaphors, Narrative and

“Truth”: South Africa's TRC, 99 Afr. Aff. 457, 461-4 (2000).

${ }^{67}$ Mohamedou Ould Slahi, GUANTANAMO DIARY (2015).

${ }^{68}$ Inside 'Islamic State': A Raqqa diary (BBC), http://www.bbc.co.uk/news/magazine-35728424.

${ }^{69}$ See Fraenkel's memorial speech for Franz Neumann, in ERNST FRAENKEL, REFORMISMUS UND PLURALISMUS, MATERIALIEN ZU EINER UNGESCHRIEBENEN POLITISCHEN AUTOBIOGRAPHIE 168-79 (Falk Esche und Frank Grube eds., 1973). See on Neumann and Fraenkel's relationship, Morris, Write and Resist, supra note 21, 202-4.

${ }^{70}$ Fraenkel was initially able to continue his work as a lawyer because he had served at the front in World War I, Ladwig-Winters, supra note 18, 91-123.

${ }^{71}$ See in particular 'Der Sinn illegaler Arbeit' (1935), discussed by Morris, Discrimination, supra note 19, $122-$ 8.

${ }^{72}$ Ernst Fraenkel, DER DOPPELSTAAT, supra note 15, 41-2.

${ }^{73} I d ., 44$.

${ }^{74}$ See Fraenkel, THE DUAL STATE, supra note 15.

${ }^{75} I d ., 3$, the decree was enacted following the Reichstag fire on 27 February 1933.

${ }^{76} \mathrm{Id}$., xiii.

${ }^{77} \mathrm{Id}$., xv. This clarification is important as German bureaucrats and others sought to make this distinction post World War II to exculpate themselves and to portray "the legal apparatus as a normative entity generally dedicated to upholding the rule of law", see Nikolaus Wachsmann, HITLER'S PRISONS: LEGAL TERROR IN NAZI GERMANY 379-83 (2004), (quoted text at 380).

${ }^{78}$ Fraenkel, THE DUAL STATE, supra note 15,3 .

${ }^{79} I d ., 57$.

${ }^{80} I d$. 62.

81 "Endowed with all the powers required by a state of siege, the National-Socialists were able to transform the constitutional and temporary dictatorship (intended to restore public order) into an unconstitutional and permanent dictatorship and to provide the framework of the National-Socialist state with unlimited powers", id., 5 .

${ }^{82}$ Rule of law notions are seen as liberal and Jewish, $i d ., 140$.

${ }^{83}$ Id., 46-7.

${ }^{84}$ Fraenkel quoted the Nazi Frank who took the purpose of the law to the point of stating that "[l]aw is all that is useful to the German people," id., 149. 
This is the version of the article accepted for publication in Human Rights Quarterly published by John Hopkins University Press: https://www.press.jhu.edu/journals/human rights quarterly/index.html

Accepted version downloaded from SOAS Research Online: http://eprints.soas.ac.uk/23313/

${ }^{85} I d$., 108, 139-49. See also Klemperer's diary entry of 7 March 1942, supra note 49.

${ }^{86}$ Fraenkel, DUAL STATE, id., 51-5, 109.

${ }^{87} \mathrm{Id} ., 30$.

${ }^{88}$ Literally "old cheese“, see Fraenkel, DOPPELSTAAT, supra note 15, 263-4.

${ }^{89}$ Id.

${ }^{90}$ Fraenkel, DUAL STATE, supra note 15, 26-7.

${ }^{91} I d ., 14-56$.

${ }^{92} I d$., 18.

${ }^{93} I d ., 19-20$.

${ }^{94} I d ., 40$.

${ }^{95} I d ., 42-3$.

${ }^{96} I d ., 73$.

${ }^{97} I d ., 73-87$.

${ }^{98} I d ., 89$.

${ }^{99} I d ., 101-3$.

${ }^{100} I d ., 171-87$.

${ }^{101} \mathrm{Id}$.

${ }^{102}$ See for example repeated references in Steinweis/Rachlin, supra note 19.

${ }^{103}$ See critical remarks by Horst Dreier, Nachwort: Was ist doppelt am "Doppelstaat"? Zur Rezeption und Bedeutung der klassichen Studie von Ernst Fraenkel, in Fraenkel, DOPPELSTAAT, supra note 15, 274, 299.

${ }^{104}$ Neumann, BEHEMOTH, supra note 16, 38 .

${ }^{105} I d ., 77$.

${ }^{106} I d ., 82$.

${ }^{107}$ See on the friend-foe distinction also the work of Carl Schmitt, Gopal Balakrishnan, THE ENEMY: AN

INTELLECTUAL PORTRAIT OF CARL SCHMITT (2002).

${ }^{108}$ Neumann, BEHEMOTH, supra note 16, 108-9.

${ }^{109} I d ., 111$.

${ }^{110} I d ., 112$

${ }^{111} I d$.

${ }^{112} I d ., 116$.

${ }^{113} I d ., 121$.

${ }^{114} I d ., 125,127$.

${ }^{115} I d$., 261, emphasis in original.

${ }^{116} I d ., 50$.

${ }^{117} I d ., 50-1$

${ }^{118} I d ., 221-361$.

${ }^{119}$ Id., 150. See further Detlev F. Vagts, International Law in the Third Reich, 84 AJIL 661 (1990).

${ }^{120}$ Neumann, BEHEMOTH, supra note $16,171$.

${ }^{121} I d ., 366-7$.

${ }^{122} I d$., 470.

${ }^{123}$ See Jürgen Bast, TOTALITÄRER PLURALISMUS: ZU FRANZ L. NEUMANNS ANALYSEN DER POLITISCHEN UND RECHTLICHEN STRUKTUR DER NS HERRSCHAFT (1999).

${ }^{124}$ Neumann, BEHEMOTH, supra note 16,80 .

${ }^{125} I d ., 396$.

${ }^{126} I d ., 397-8$.

${ }^{127} I d ., 400$.

${ }^{128} I d$., 402.

${ }^{129} I d$., 403 (emphasis added).

${ }^{130} I d$., 444.

${ }^{131} I d ., 447$.

${ }^{132} I d$...

${ }^{133}$ In Carl Schmitt's decisionist "legal thinking, law is nothing but a technique for transforming the political will into legal form". Franz Neumann, The Rule of Law: Political Theory and the Legal System in Modern Society 285 (1986), quoted by, and discussed further in Morris, Discrimination, supra note 19, 207.

${ }^{134}$ Neumann, BEHEMOTH, supra note 16, 448 .

${ }^{135} I d$., 452.

${ }^{136} I d ., 453$. 
This is the version of the article accepted for publication in Human Rights Quarterly published by John Hopkins University Press: https://www.press.jhu.edu/journals/human rights quarterly/index.html

Accepted version downloaded from SOAS Research Online: http://eprints.soas.ac.uk/23313/

137 "It has been maintained that National Socialism is a dual state, that is, in fact, one state within which two systems are operating, one under normative law, the other under individual measures, one rational, the other the realm of prerogative. We do not share the view because we believe that there is no realm of law in Germany, although there are thousands of technical rules that are calculable. We believe that the monopolists in dealing with non-monopolists rely on individual measures and in their relations with the state and with competitors, on compromises which are determined by expedience and not by law." Id., 467-8.

${ }^{138} I d$., 458.

${ }^{139}$ See for further discussion, Bast, supra note 123, 280-7.

${ }^{140}$ Peter Hayes, Introduction, BEHEMOTH, supra note 16, vii.

${ }^{141}$ However, see for a critical account of Neumann's work, Walter Laqueur, 'Uncritical Theorists Who Misread the Nazis', Standpoint (September 2013), http://standpointmag.co.uk/books-september-13-uncritical-theoristswho-misread-the-nazis-walter-laqueur-frankfurt-

school? page $=0 \% 2 \mathrm{C} 0 \% 2 \mathrm{C} 0 \% 2 \mathrm{C} 0 \% 2 \mathrm{C} 0 \% 2 \mathrm{C} 0 \% 2 \mathrm{C} 0 \% 2 \mathrm{C} 0 \% 2 \mathrm{C} 0 \% 2 \mathrm{C} 0 \% 2 \mathrm{C} 4$.

${ }^{142}$ Hayes, supra note 140 , vii.

${ }^{143}$ See for his thoughts on the legality and legacy of the Nuremberg trials, Franz Neumann, The War Crimes Trials, 2 World Polit 135 (1949).

${ }^{144}$ Hayes, supra note 140 , viii.

${ }^{145}$ See on Fraenkel, Morris, Discrimination, supra note 17; Morris, Write and Resist, supra note 19; and on Neumann, particularly Scheuerman, RULE OF LAW, supra note 18.

${ }^{146}$ See Alfons Söllner, NEUMANN ZUR EINFÜHRUNG 79-82 (1982).

${ }^{147}$ However, Neumann was also criticised by other members of the Frankfurt School for his lack of attention to psychological and sociological factors. See id., 83-4, 89-91.

${ }^{148}$ See on the influence of Karl Marx and Max Weber on this analysis, e.g. Duncan Kelly, Die Herrschaft des Gesetzes: Max Weber und Franz Neumann, in KRITISCHE THEORIE DES STAATES: STAAT UND RECHT BEI FRANZ L. NEUMANN 109-31 (Samuel Salzborn ed., 2009).

${ }^{149}$ See for example Kanan Makiya, REPUBLIC OF FEAR: THE POLITICS OF MODERN IRAQ (1989); Hisham Matar, IN THE COUNTRY OF MEN (2006) (on Libya); Kang Chol-Hwan and Pierre Rigoulot, THE AQUARIUMS OF PYONGYANG: TEN YEARS IN THE NORTH KOREAN GULAG (2001).

${ }^{150}$ See Meierhenrich's analysis drawing on Ernst Fraenkel's dual state, supra note 23, 4, according to whom "from colonialism to apartheid, South Africa was ruled by an ever-changing dual state". He also discusses Chile (1830-1990) as an example of a dual state, id., 295-313.

${ }^{151}$ See e.g. Maha Abdelrahman, EGYPT'S LONG REVOLUTION: PROTEST MOVEMENTS AND

UPRISINGS 16-20 (2015), and Adam Hanieh, Mapping the political economy of neoliberalism in the Arab world, in RESEARCH HANDBOOK ON POLITICAL ECONOMY AND LAW 280-97 (Ugo Mattei and John D. Haskell eds., 2015).

${ }^{152}$ See for example Sudan's National Security Act of 2010.

${ }^{153}$ See further, Andrew Norris, Review: A Mine That Explodes Silently: Carl Schmitt in Weimar and After, 33 Polit Theory 887 (2005).

${ }^{154}$ For example the invocation of Islamic law by the Islamic State of Iraq and Al-Sham (ISIS) to justify violations committed against Yazidi women and children. UN Human Rights Council, "They came to destroy": ISIS Crimes against the Yazidis, UN Doc. A/HRC/32/CRP.2, 15 June 2016, particularly para. 154.

${ }^{155}$ Fraenkel, DUAL STATE, supra note 15 , Introduction, xvi.

${ }^{156}$ See e.g. Heidrun Budde, Fraenkel's "Doppelstaat" und die Aufarbeitung des SED-Unrechts, DEUTSCHLAND ARCHIV ONLINE, 29 November 2013,

www.bpb.de/geschichte/zeitgeschichte/deutschlandarchiv/174168/fraenkels-doppelstaat-und-die-aufarbeitungdes-sed-unrechts; Scheuerman, supra note 18.

${ }^{157}$ Neumann, BEHEMOTH, supra note 16, 440-58. See for a later development of his thinking also Neumann's seminal 'The Concept of Political Freedom', reprinted in Scheuerman, RULE OF LAW, supra note 18, 195230.

${ }^{158}$ See on Otto Kirchheimer, Scheuerman, id.

${ }^{159} I d ., 2$.

${ }^{160}$ Neumann, BEHEMOTH, supra note 16, 158-9.

${ }^{161}$ See, in contrast, Klaus Theweleit, MALE FANTASIES, VOL. 1: WOMEN, FLOODS, BODIES, HISTORY (1987); MALE FANTASIES, VOL. 2: MALE BODIES- PSYCHOANALYZING THE WHITE TERROR (Press, 1989).

${ }^{162}$ See Upendra Baxi, THE FUTURE OF HUMAN RIGHTS, Third Edition, 27-32 (2008), on Hannah Arendt's notion of radical evil and contemporary human rights, and throughout on the notion of, and struggle for human rights. 